\title{
Culture, contexts and connections: A conversation with Dennis Klass about his life and work as a bereavement scholar
}

This article is a conversation between Edith Maria Steffen and Dennis Klass, the coeditor of the paradigm-shifting publication Continuing Bonds: New Understandings of Grief (1996). Steffen and Klass co-edited the anthology Continuing Bonds in Bereavement, New Directions for Research and Practice (2018) that follows the developments in the continuing bonds model of grief over the last two decades. Klass got into the field of bereavement studies initially through working with Elisabeth Kübler-Ross and continued by engaging in ethnographic research with a self-help group of bereaved parents. As he tried to make sense of how they were coming to terms with their children's deaths, he tested different theories against the data from the bereaved parents, which led him to discard conventional theories and instead apply what he saw in Japanese ancestor rituals to the practices of the bereaved parents. Klass discusses how the idea of continuing bonds was born, how the 1996 publication came about, how it was received, and how he took this work further. He looks back on his life and work and looks ahead towards work that still needs to be done. When the conversation turns to Klass' idea that consolation is a neglected area in bereavement Steffen and Klass discuss whether the time may be ripe for this idea being taken up and developed. The conversation ends with Klass giving advice to novice bereavement scholars, which could be summarised in his motto, follow the data.

Keywords: continuing bonds; consolation; cross-cultural research; ethnography; rituals; self-help 
I wasn't out to change the world - I just wanted to describe the bereaved parents and the self-help process as well as I could.

In the world of bereavement studies, Dennis Klass has few peers. As co-editor of Continuing Bonds: New Understandings of Grief, the revolutionary volume which signalled a paradigm shift in bereavement scholarship when it was published in 1996, he has been at the forefront of radical changes in Western understandings of grief and bereavement. For most of the $20^{\text {th }}$ century, in the shadow of Freud's 1917 publication Mourning and Melancholia, the common dictum had been that bereaved people should 'let go' of the deceased and 'move on'. Klass, Phyllis Silverman and Steven Nickman (1996) radically opposed this idea, pointing to cross-cultural research and detailed qualitative studies based in specific local settings. This research demonstrated that ongoing relationships with the deceased are normal and widespread. The message in their 1996 book was not only powerful in its content and import, it was also framed in powerful terms that left readers in no doubt about the authors' critical stance on the dominant paradigm and the perspective they proposed:

We suggest that the dominant model of grief is based on inadequate assumptions about the nature of the self and is based in inappropriate social scientific methodology used to study bereavement. We note that because the model is based in the unexamined assumptions of our age, the model shows remarkable resiliency in the face of data (Silverman \& Klass, 1996, p. 22). 
We propose that it is normative for mourners to maintain a presence and connection with the deceased and that this presence is not static (Silverman \& Klass, 1996, p. 18).

Although he wasn't 'out to change the world', as he put it, Klass made a significant contribution towards such change, and his outstanding achievement has just been recognised in the form of the Lifetime Achievement Award of the world-leading bereavement society ADEC, Association for Death Education and Counseling, which he was awarded at ADEC's $40^{\text {th }}$ Annual Conference in Pittsburgh, PA, USA, this April.

When I was researching continuing bonds as part of my doctoral research during counselling psychology training here in the UK, I found in Dennis Klass a perspective that brought together many of my own passions and concerns: Here was a psychologist who leant towards the sociological and anthropological end of the discipline, who embraced a critical, postmodern, and constructionist stance, who was interested in uncovering power relationships in academia and clinical practice and who prioritised ordinary bereaved people's own voices over the voices of so-called 'experts'. In addition, here was someone interested in existential issues, in religion and spirituality and open to the multiplicity and diversity of ways people believe and practice. I was amazed when, after he read some papers that came out of my doctoral research, he wrote to me saying that in me he recognised a kindred mind (Steffen \& Coyle, 2010, 2011). It was therefore a particular honour for me to work with Dennis Klass as we co-edited a second volume about continuing bonds, the recently published Continuing Bonds in Bereavement: New Directions for Research and 
Practice (2018). Having had many a Skype session with him over the past few years, when Mortality asked me to conduct a cross-Atlantic interview with Dennis Klass about his life and work, I was happy to comply. The following is an edited version of our Skype conversation. In editing it, I have tried to bring out the core messages while maintaining a flavour of the conversation and a sense of his personality. It is, after all, partly due to his personal directness and vehemence that the message about continuing bonds has been so convincingly made and so powerfully received.

\section{Laying the groundwork: Listening to bereaved parents}

I just sat and listened and talked with them. This was real grounded theory, not just going and talking to a bunch of people and taking notes. There is a recursive cycle: you ask your question, and reformulate the question from what you hear, and do that again and again.

EMS: How did you first become interested in bereavement research and practice?

DK: It's a complex story. I was beginning my first year in doctoral studies at the University of Chicago. Although I had a scholarship to pay for my tuition, I had nothing to live on. I had a two-year-old baby, and my wife was pregnant with our second child.

I saw a notice for a research fellowship in the University hospitals chaplain's office. Part of my responsibilities would be assisting in a seminar with a psychiatrist named Elisabeth Kübler-Ross. So I found myself recruiting terminally ill patients for her seminar and following up after they'd been interviewed. Kübler-Ross's book $O n$ 
Death and Dying (1969) that started the modern death and dying movement came out in December of the year I was assisting in the seminar.

Later when I began teaching, I often used examples from the seminar. Then I developed a course in Death and Dying. It was quite unheard of to teach about that topic at that time. It made me a local expert. There were stories about me in the paper and TV interviews. Then I was invited to help a group of bereaved parents who wanted to start a local chapter of a self-help group.

EMS: So people had heard about you as someone who was interested in bereavement and might be able to help them?

DK: Yes. After the parents approached me, I checked and realized that there was no relevant literature. I saw that these people were experiencing a religious/spiritual problem. They were asking: 'Where was God when my child died?' They did not know how to make sense of their child's death. As they learned how to be a bereaved parents self-help group -- you can call it spiritual, you can call it religious - they lit candles together; they had memorial meetings; they wrote letters to their children; they reported communications with their children.

EMS: So you were seeing a connection between the bereavement and the parents' religious/spiritual beliefs and practices?

DK: Yes. Bear in mind that I had a particular background here. My dad was Jewish, my mother North Irish Protestant. So the question of what is this thing called religion 
is an interesting question to me at a very deep level. I had done some personal searching. I studied religious leaders. The first academic paper I published was a psychological study of Paul Tillich using Eric Erikson's psycho-historical method. But that wasn't working. Theologians and historians didn't like my psychologizing their topics. And it wasn't deeply interesting to me either.

EMS: Had you done a degree in theology?

DK: Yes. I have a seminary degree. I loved it as an academic study. I was a pastor for two years, but I realised in the first weeks that I was in the wrong place. The questions of how people make meaning in life and form communities around those meanings were the questions I was interested in. As the parents talked about the issues their children's deaths presented to them, I recognised that what we were seeing here was a religious/spiritual group process without the historical and cultural baggage of organized religion.

EMS: It's almost as if they invented their own religious process or ritual that came naturally to them in terms of how they felt, coming from the urge to commemorate or to continue something.

DK: That's correct. It was what I had been looking for, a place to observe people coming to terms with the human condition. I slowly realized that they were doing so in ways that I could describe using ideas from both the social sciences and from the world's religious traditions. 
Early on they asked me to write a column for their newsletter. I wrote about how I was understanding what I was observing. So the first writing I did on this group was not about them; it was for them. I set a rule for myself: If I could not say to bereaved parents what I believed about how they were coming to terms with their children's deaths then, I couldn't say it to anybody else.

EMS: Your interest in bereavement seems to have grown from the ground up, from that involvement with those parents. How did that marry with your training, with where you were coming from academically? Did something bridge that for you?

DK: Academically, my life has been a series of very fortuitous accidents. I knew about qualitative research; we called it participant observation in those days. Right when I began listening to the parents, my wife was doing a $\mathrm{PhD}$ in early childhood education. Ethnographic methods played a big part in the sociology of education. Her dissertation research was an ethnographic study of a day-care centre, so I had a consultant in the ethnographic method. We often talked about similar dynamics between parents whose kids had died and mothers and fathers bonding with their live babies. It was part of the conversation in our marriage.

EMS: And it sounds like all these different influences, then, really came to bear on your work with this group of bereaved parents. Can you say a bit more about how this work developed?

DK: I didn't publish anything for a few years; I just listened and talked with group members. This was real grounded theory -- not just talking to a bunch of people and 
taking notes. There is a recursive cycle: you ask your question, reformulate that question from what you hear, and do that again and again until what you are hearing and what they are saying correspond. The researcher is not separate. I was part of the process. A description of the ethnographic researcher that I like is stranger and friend. I was part of the intellectual movement towards observation at that time. Jane Goodall was in the African jungle watching and interacting with chimpanzees. Dian Fossey was observing the mountain gorillas. That natural research was going on. That's what I did - I went to their world.

As my role in the group developed I would be asked to speak at monthly meetings and at regional and national gatherings. I would say, 'Here's how I understand about what I am hearing from you.' Afterwards some people would tell me what was good, and what I had missed. The bereaved parents were an integral part of the process.

I've been in rooms with 1000 people where everybody had a child die except me. It's a mind-bending experience that makes you think about what is important in life. That's the gift I was given. They had paid a big price to be there. I had not paid the dues. I could help with the group process. For example, we had to figure out how to do the business of a group when one of the symptoms of parental bereavement is an inability to concentrate? I didn't stay in all of the groups. We started a group of parents of murdered children. After two years some of the parents got uncomfortable with somebody there whose child had not been murdered. I decided not to attend monthly meetings, though the leaders still called me sometimes to help them think something through. 
EMS: What fascinates me as a counselling psychologist is this overlap between your presence as a researcher and your therapeutic presence. Would you say that those two elements were interwoven in your work with them?

DK: Yes. The difference between this and therapy is that the therapist has to engage the person about the issue. I didn't have to do that. It was a self-help group. The revelation that allowed me to stay was that I was not responsible for them individually. I was only responsible to the group. Meetings started with everyone going around the circle to introduce themselves. I would say, 'I'm not a bereaved parent; I'm here as a friend.'

\title{
Making sense: Testing theories against the data
}

\author{
When I gave workshops, I would begin with: 'Remember somebody who \\ died. Who were they in your life when they were alive? Who are they in your \\ life now? That's your data. If anything I say doesn't make sense in terms of \\ that, forget it! Always test against the data.'
}

EMS: And when you went to these meetings or conventions or conferences, did you then start to talk to professionals or researchers, academics, other therapists and so on in the more professional world of bereavement?

DK: I tried to. I tried to communicate what I was finding. The death and dying movement was very new. Hospices had not yet made it into the medical system; they were still largely run by volunteers. A new organization was founded, the Forum for 
Death Education and Counselling. It's now called the Association for Death Education and Counselling (ADEC). Their newsletter was The Forum. I wrote something about the parents' group. And I said look, there's this really exciting new thing - self-help. One response was, well, they're not professionals. They don't know what they're doing. They keep talking about the kids; they won't let go. In other words, the first response among the people studying bereavement was that they understood the parents' grieving better than the parents did. Mental health professionals claimed that grief was their bailiwick. That has been consistent. Notice that the descriptions of complicated grief say $10-15 \%$ need professional intervention. Nowhere do they say the people should join a good self-help group.

EMS: And why do you think it's still like that?

DK: Well, I'll be very honest. I think, when we study grief, we need to ask the question of how much of our self-interest is involved. The major reason, at least in the US, for getting the complicated grief diagnoses into the DSM is so they can get thirdparty payments. They were clear about that. ${ }^{\mathrm{i}}$

EMS: Are you referring to interests in the professional community to provide a paid service in order to make a living?

DK: We don't have to make it that personal. Go to Michel Foucault who has shown how a problem is defined serves the political and economic interests of those who hold the power. Foucault helps us understand the complicated grief diagnosis. 
EMS: Right. So, when you got rebuked with the self-help research and you're trying to get the knowledge from the bereaved people to the professionals, were there some receptive voices or other like-minded people?

DK: There were other people. David Balk had done his research on bereaved siblings in the self-help group. We met when he came to report his findings at the state convention. Nancy Hogan understood. I first met her at the group's national convention. Bob Kastenbaum, the editor of Omega, understood what I was doing. And there were some others who understood it. And I just kept plugging along. I didn't know that this concept of continuing bonds would emerge; all I knew was that the parents were doing something few other people were writing about, and that what we now call continuing bonds, was an important part of the process. However, I didn't know how that piece fit in. I just kept listening. I wasn't out to change the world - I just wanted to describe the bereaved parents and the self-help process as well as I could.

EMS: I wonder if what has made your contribution so powerful is that it doesn't come from an intellectually devised idea, but that it was simply being with those parents and hearing what they were saying and giving them the space to develop something out of their own needs and within the dynamic of their group rather than following some kind of pattern that someone had devised for them.

DK: Bob Neimeyer had a really nice way of talking about that dynamic. He said psychotherapy is science. The client is trying to figure out how her or his life works and why it's going wrong, and the therapist is trying to figure it out too - it's a shared 
scientific project. Well, I was trying to figure out what the parents were doing. They didn't understand their life. I did not need to design research surveys and instruments et cetera when they are writing their lives in poetry and prose and sharing their lives. All of the data was there.

EMS: You were bringing an almost anthropological or ethological mind-set to the field of bereavement, rather than a psychiatric or psychological mind-set.

DK: Yes. Precisely. And therefore, anything anybody says, from whatever point of view or discipline, I always go back and ask whether what they say would help me understand what I heard in 20 years of sitting in meetings. When I gave workshops, I would begin with: 'Remember somebody who died. Who were they in your life when they were alive? Who are they in your life now? That's your data. If anything I say doesn't make sense in terms of that, forget it! Always test against the data.'

EMS: It's interesting you mentioned Foucault. If you take a constructionist perspective, can we actually ever just neutrally observe data?

DK: And the answer is no, but we can be aware of our bias and presuppositions and bracket them, so we listen as neutrally as we can. Especially, when we see or hear something that we cannot understand with our present mind set, if we don't ignore it we can use it to expand or revise the mental constructs we brought to the project. And we can compare what we heard with what other people heard - like Phyllis Silverman saying she had found the same thing. In the case of the bereaved parents, I could check how I understood against how they were understanding themselves. 
EMS: So you would have already brought some theories even to your initial observation.

DK: Yes, of course. We bring what we have to any new experience. I was a member of a study group that met for five years. We called ourselves the St Louis Study Group in Applied Psychoanalysis. We had people from the Psychoanalytic Institute and people doing other kinds of scholarship. We read each other's papers. Jane Loevinger was a member. Her Ego Development theory is brilliant but too complex to be widely adapted. Loevinger took Piaget's ideas, Kohlberg's moral development, as well as ideas from many branches of psychoanalysis and asked how those ideas might apply to ego development. So it was pretty high-level stuff that we were talking about. And I got a lot of feedback. I was in constant intellectual dialogue, but it was not with people in what we now call bereavement studies.

EMS: You mentioned Piaget, and you mentioned Erikson. And there was something around stage theories that was quite fashionable at that time. Did you use stages in any way yourself?

DK: Well, I knew Kübler-Ross's stages well from her seminar. I sat in the first meeting wondering: Is this bargaining? Is that denial? As I drove home after that first meeting, I said to myself, well, that didn't work (laughing). I started listening to the parents in December 1979. John Bowlby published the third volume of his trilogy in 1980. I read Bowlby's theory of grief within that year and I concluded that the attachment model as he formulated it didn't work either. 


\section{Making the connection: Japanese ancestor rituals as a useful model}

They lit candles; they released balloons - it looked similar.

EMS: So is this what you were saying earlier - that you were taking these ideas and testing them against the data from the parents that you've been sitting with. And those ideas about grief didn't work. So, what did work? Did anything work to make sense?

DK: I started to see patterns in how they found consolation, in how they made sense, in how they interacted with each other, and how they understood their grief. I don't think I described the patterns well enough in the first book, Parental Grief: Solace and Resolution (1988), and the parents told me so. I think I did better in the second book about the group, Spiritual Lives of Bereaved Parents (1999). And then I wondered, is there anything else like what I saw in the parents. I studied the Japanese ancestor rituals and those rituals made the data from the self-help group make sense. Japanese ancestor rituals are a very old way of continuing bonds. The rituals provided a model that I thought I could use. The continuing bonds model came out of cross-cultural studies. One of the chapters in Continuing Bonds: New Understandings of Grief describes Japanese ancestor rituals.

EMS: How did you come across the Japanese ancestor rituals? Was it just by chance? Can you remember any sort of significant moment? 
DK: Oh yes. Again I can say that my academic life has been a series of fortuitous accidents. My son's high school had a summer program to go abroad and live with a family. Although he did not speak the language, he went to Japan. They placed him in the home of a Buddhist priest family. Buddhist priests in Japan are basically in the funeral business. His host family were delightful, wonderful people. The experience was powerful enough that he double majored in Asian Studies and Math at Oberlin College. He had done a reading course in ancestor rituals. When I asked, he pointed me to the right books. After he graduated, my son worked in Japan for three years in a firm that distributed American semiconductors. When we went to visit him we stayed in his host family's temple for a while. I was able to observe the rituals. I could see the connection with the bereaved parents.

EMS: And that is so fascinating - that the current Western models that you had at your disposal didn't fit, but what you saw in Japan fitted. Can you say more about how you made those connections?

DK: First of all, the ancestor rituals and the self-help group looked the same. Obon is a three-day-festival in the summer when the spirits of the dead return. Families light lanterns to guide the spirits back. What you say when the ancestors come back at Obon? You bow low and thank them for coming. And at the end of the ritual you say goodbye and invite them to come back next year. It's very human. The bereaved parents didn't know Japanese ancestor rituals, but they lit candles at the winter Holiday Memorial Service. They released balloons. It looked similar. I remember the first holiday candlelight service after I had been in Japan. Nine hundred people holding candles lit a dark room. And I knew at a deep level that for the parents their 
children had come back for a while. So it was easy to make the connection. The parents and the Japanese talked about their interactions with the spirits the same way. One mother said her son came back when she didn't know how to solve this problem, and all of a sudden Jimmy was there and Jimmy said: 'Mum, this is what we should do.' And the Japanese would say they had a dream when they didn't know how to handle a problem. The spirit came in the dream with a solution. The experiences were so similar.

EMS: And how did you use these insights?

DK: When I wrote about Japanese ancestor rituals I included some anthropological material which describes the external aspects, but I was wondering about the internal experience. Japanese people don't like to talk about their inner self, but I found many examples in the literature. Some Japanese students at my university heard about my interest and would drop by to talk. I would ask them about what happened in their families when someone died or when they performed ancestor rituals. When they didn't know something, they would ask their mothers on the phone. So as I read the scholarly work on the Japanese rituals, I had constant feedback from real families. Of course, there were major cultural differences I had to understand. The major difference is dependence and autonomy. In traditional Japan the basic cultural value is mutual dependence. The basic cultural value in the United States is autonomy. You have to work that one through. 
EMS: When you say you have to work that one through, do you mean now as the scholar or as the parent living in a society where individuation and separation are valued? Are they different processes?

DK: I had to understand the difference and how each of them works as the cultural context of grief. My wife and I were on the same track there. As I mentioned earlier, she did an ethnographic study in a day-care centre. She asked what values were being transmitted. In the 1970s and 80s conservative politicians regarded day-care as a kind of socialist venture. People thought that single mothers should stay home to raise their kids, and that day-care would turn them into little communists. It is easy to forget how different things were in those days. My wife found that even in the social setting of day-care, the values that were transmitted were about autonomy. Her first book was The Autonomous Child: Day-care and the Transmission of Values (1986).

\section{Breaking the mould: Publishing about Continuing Bonds}

We just didn't know it was this revolutionary.

EMS: Thinking about all these different aspects perhaps as the preparatory ground for the publication of Continuing Bonds: New Understandings of Grief in 1996, which has always been described as inducing a paradigm shift in bereavement scholarship and being really radical and revolutionary, I was wondering, were you aware of that at the time of publication? 
DK: When I went to a conference in New York, Phyllis Silverman came up to me and said she had read what I wrote about the bereaved parents, and that she and Bill Worden had found the same thing in the Harvard Child Bereavement Study. She and I looked around and realised that a lot of people were finding the same thing. So we decided to do the Continuing Bonds anthology. Did we know it would be revolutionary? Yes. We knew that it was a revolt against the Freudian model. We just didn't know it was this revolutionary.

EMS: When you say, 'this revolutionary', can you say more about what happened around the time or what the reactions were? Were they hostile at first or were they mixed? How was the Continuing Bonds book received?

DK: People who were doing grief counselling understood almost immediately. They had clients who talked about how important people who had died were still in their lives. People doing research didn't see it as quickly because they were caught up in their own theories. Almost ten years later, however, by the time I wrote the article about continuing conversations about continuing bonds in 2006, we'd kind of already won the game.

EMS: You might say the world was ready for it.

DK: Yes. Several other people found the same thing around the same time. We were not the only ones. We never said we found something new; we said we were articulating an emerging consensus. And the time was right. For example, Tony Walter had written in the first issue of Mortality that the purpose of grief is to 
construct a durable biography. The Continuing Bonds anthology came out shortly after Tony's article. Tony immediately wrote an incredibly positive review. He mentioned that he had done something similar but that we had more data. What generosity. He had struggled to come up with his formulation, and he just gave it away.

EMS: And how was the name continuing bonds actually coined?

DK: We were looking for a name for what we were describing, and for a title for the book. We first called it inner representations, which is wrong, because it's not just inner, it is also social. I had asked my wife to help me. Then one Saturday morning, when we were in the kitchen putting away the groceries, she suddenly said 'Continuing Bonds.'

EMS: And it fits so well with the model that the phrase emerged in this everyday family situation of putting away the groceries together.

DK: We tried it in different sentences and different contexts and it worked. I called Phyllis, she called Steve, and that was it. So it was Carol, my wife, the child development person working with parent-child bonds, who coined the term.

EMS: And you have described in the new book how important it was to use the word bonds rather than attachments. 
DK: Precisely. An attachment, even as the attachment theorists use it now, is a psychiatric description. You can describe it in individuals. A person forms strong or weak attachments, et cetera. There's a whole literature in grief about people's attachment style. You can describe an attachment in individuals, but you cannot describe a bond in individuals; a bond is a relationship.

EMS: Is it two-way? Or even more than two-way?

DK: Two-way, three-way and more. There is even a national bond. What we now know as continuing bonds is a much larger concept than we first thought.

EMS: Then in 2005, you published the book Dead but not Lost, which seemed to take things even further away from mainstream psychology.

DK: If there's a pattern that I look back on that I'm proud of, it is: Follow the data. Find out what's going on and see if you can explain it. That's what scholarship is. Bob Goss joined our department. He read the continuing bonds book and suggested looking at the Tibetan Book of the Dead as a book for the bereaved. So here was grief in another cultural context. Bob is an ex-Jesuit who had left the order to be with his partner. His partner died in the AIDS epidemic. So Bob understood bereavement. His $\mathrm{PhD}$ was in Buddhist studies. He had written his thesis on Tibetan Buddhism. So another fortuitous accident. How often does someone who reads Tibetan suggest writing together? After we published that article we were invited to Naropa Institute to study how American converts to Tibetan Buddhism described their grief. 
When it was clear by then that continuing bonds had replaced the Freudian model of grief, we asked what other paradigm shifts there had been around continuing or discontinuing bonds. Bob and I were trying to understand grief in Islam. I learned on a web site that in Saudi Arabia Wahhabi Muslims had destroyed the cemeteries where the Prophet's relatives were buried. They said Muslims should not continue their relationship with the dead but should trust Allah. They were as adamant about not maintaining a relationship to the dead as any Freudian ever was. We found other examples including the Deuteronomic reform in ancient Israel and under Maoism in China. And we found places where the paradigm had changed in a different way. How did the veneration of saints come into Catholicism and how did that centralise so that the saints associated with Rome were more powerful than local saints? In other words, we're talking about continuing bonds and cultural change.

EMS: Again, something about power comes into play. Who's got the power? If you have your local saints or your personal relationships to your dead, that takes power away.

DK: Precisely. I do not think that the majority of people in bereavement studies understand how culturally bound the current research and practice in bereavement is. I think the majority of people don't understand, for example, that you can draw a relationship between what happens in counselling offices and what happened in the destruction of cemeteries under King Josiah in the Bible.

\section{Conclusions and new directions: Continuing concerns in bereavement research and practice}


Consolation is a neglected area in bereavement research and practice. It has not been integrated into bereavement studies. In bereavement studies we continue to want to regard grief as trauma and not as tragedy. We want to make it something you can get over, or at least grow from.

EMS: So where do you see the continuing bonds model going? Do you think it has fulfilled its function or mission? Do you think it has a role to play in the future of bereavement research and practice?

DK: Well, you and I edited a book that says it does, so it had better (laughing). I don't know where it's going. Who would have thought that one of the major parts of understanding Facebook and grief would turn out to be continuing bonds? Who would have thought the sense of presence would turn out to be such an interesting phenomenon to study as you have? Who would have thought that a person studying Mesopotamian texts from 4000 years ago would find the significance of family bonds and challenge 150 years of archaeologists' explanations? I think there's a future. The continuing bonds model of grief is not a theory; it's a description of phenomena. What's been amazing, as the new book you and I edited shows, is that people have found those phenomena in so many places - from Facebook to ancient Mesopotamia. And they've seen analogies of those phenomena in other contexts.

EMS: And how do you see your own life and career relating to the continuing bonds model? Has that been the main thing for you or could it have been something different? 
DK: Well, I said there were a lot of wonderful accidents. I am pleased to have been part of something this big and interesting. I'm also sorry that other things that I think are true have not been accepted the way continuing bonds has. Consolation was in the first book I wrote about bereaved parents. I have, since then, written about consolation and explored its nature. Consolation is a neglected area in bereavement research and practice. It has not been integrated into bereavement studies. In bereavement studies we continue to want to regard grief as trauma and not as tragedy. We want to make it something you can get over, or at least grow from. What I just said has been a critique of the death and dying movement from the beginning. Lyn Lofland wrote a book in 1978, about the then-new concept of hospice. He called it the Happy Death Movement.

EMS: I think it's great you're bringing in this topic of consolation, because I think the world is ready for that. I think it's waiting, just as it had been for continuing bonds.

DK: Does this mean you and I should do another book (laughing)? I would like to be as optimistic as you. I wrote about consolation in my first book on bereaved parents in 1988. That's a long time to wait for the idea to catch on.

EMS: It is absolutely ripe. Think about compassion. Who would have thought a couple of decades ago that compassion is now available on prescription? You can get Compassionate Mind treatment, compassion-focused therapy, self-compassion practice. It has been a big movement in mental health. 
DK: Wonderful.

EMS: So I think consolation in bereavement seems to just be crying out to be rediscovered. Because it's actually a central process, as you say.

DK: You're giving me hope, but if you take a look, there is still no entry for consolation in the indexes of the major books on bereavement.

EMS: Because what is required is some kind of empirical research study.

DK: Well maybe. I hope somebody gives it a try.

EMS: Another question I wanted to ask is whether you have any regrets.

DK: Of my life? I'm 78 years old. I'm not going to get another 78 years. Sometimes I'll just be going along, and I'll see my name mentioned somewhere or somebody else doing something about continuing bonds. And I think what a lucky guy I am. But it's nothing I did. The bereaved parents figured it out. I just reported what they said.

EMS: Well, do you really believe that? Because, I mean, it takes someone to be in the right place at the right time, perhaps, but with the right capacity to hear it, to see it, to listen to it, to use it. 
DK: And a guy who's willing to look at the experts in the field and tell them they're wrong - somebody as contrary as I am. My character trait that people find grating is also very helpful. I remember when Phyllis and I were planning the book and thinking about the tone it should have, and I wrote to her, saying this needs to be a really inyour-face book. That book was pugnacious. It said that the theory is wrong and that we need to get it right. And Phyllis could also be really pugnacious. She was a real character. So, yes, I was at the right place, at the right time, put things together, was intellectually prepared, was emotionally prepared. And then a fortuitous accident: I found the bereaved parents' self-help group. All of those things came together, and I could not be more pleased. If it weren't for the serendipity who knows how things might have turned out for me?

EMS: So, if you were back at the start of your career now, what would you do? Would you invent another model or what do you think you would be doing?

DK: That's a very good question. What I was doing was historical research using psychology to study religions. I had so many questions. How I would have asked them differently had I not found the bereaved parents? I have no idea. It certainly wouldn't have been as interesting; it would not have taken me to the fascinating intellectual places I've been. It would not have gotten me in touch with the variety of people, in both the bereaved parents and in bereavement studies.

EMS: It's interesting to hear you say continuing bonds is always about more than just a relationship with one deceased person, but it's about a cultural continuation. 
DK: It's how we are bonded together. It's remembering the dead together. That is what makes Lincoln's Gettysburg Address a core part of the US cultural narrative. Remembrance Day creates who the British are as British. What created the Australians' feeling of themselves as Australians? The war memorial in Canberra. The bonds with the dead create the culture. But don't forget after Trump was elected there were white nationalists marching in America carrying torches like Nazis, shouting 'blood and soil, blood and soil' as they protested taking down monuments to the Confederate dead. The bond with the dead can be for good or ill. Let's not romanticize it. But we can learn to understand it.

EMS: Thanks for adding that. Can I just ask one last question: what advice would you have for bereavement scholars just starting out?

DK: When we study grief and death we are in the presence of a profound reality in the human condition. Scholars will do their best research if they open themselves to the reality that is death and grief. If someone important to you has died, start with who you were then, how the death changed you, and where in your life that person is now. You know that context well, so look deeper and at the history and cultural meanings. Or you can do something like I did when I sat listening to the bereaved parents. Spend several days at a dying person's bedside. Go to a war memorial or war cemetery and let yourself feel as you read the names. Open yourself to the pain and truthfulness in front of you. That's your data. Observe everything. Describe everything you can. Don't leave anything out just because you can't explain it. Don't narrow down until you have fully experienced it. If you let yourself experience the reality of grief as 
fully as you can, whatever aspect you choose, and whatever methodological choices you make, your research will be the best you can do.

EMS: I'm sure that it's really important, but hard advice, especially now when people are under pressure to produce research results and output faster than ever. Thank you very much for this fascinating conversation.

\section{Acknowledgement:}

We would like to thank Nancy Joy Long for reading the manuscript and making helpful suggestions for improvement.

\section{Notes on contributors}

Edith Maria Steffen, PsychD, CPsychol, AFBPsS, FHEA, HCPC reg. is a chartered counselling psychologist and lecturer on the doctorate programme in counselling psychology at the University of Roehampton, London, UK. Her research focuses on continuing bonds, sense of presence experiences in bereavement and meaningoriented grief therapy. She has published articles in journals such as Death Studies, Omega: Journal of Death and Dying and Mental Health, Religion \& Culture and has contributed a number of chapters to anthologies. She is co-editor of the recently published anthology ContinuingBonds in Bereavement: New Directions for Research and Practice.

Dennis Klass, $\mathrm{PhD}$, has been active in the study of death, dying and bereavement since 1968. He ison the editorial board of Death Studies and Omega: Journal of Death and Dying. He is the author of The Spiritual Lives of Bereaved Parents, coauthor of Dead but not Lost: Grief Narratives in Religious Traditions, coeditor of Continuing Bonds: New Understandings of Grief, and co-editor with Edith Maria 
Steffen of Continuing Bonds in Bereavement: New Directions for Research and Practice.

\section{References}

Bowlby, J. (1998). Attachment and loss (Vol. 3). Loss: Sadness and depression. London: Pimlico.

Freud, S. (1917). Mourning and melancholia. In J. Strachey (Ed. and Trans.), The standard edition of the complete psychological works of Sigmund Freud (Vol. XIV) (pp. 252-268). London: Hogarth Press.

Goss, R.E., \& Klass, D. (2005). Dead but not lost: Grief narratives in religious traditions. Walnut Creek, CA: Altamira Press.

Klass, C.S. (1986). The autonomous child: Day care and the transmission of values. New York: Falmer Press.

Klass, D. (1988). Parental grief: Solace and resolution. New York: Springer.

Klass, D. (1999). The spiritual lives of bereaved parents. Philadelphia, PA: Brunner/Mazel.

Klass, D. (2006). Continuing conversation about continuing bonds. Death Studies, 30, 843-858.

Klass, D., Silverman, P. R., \& Nickman, S. L. (Eds.) (1996). Continuing bonds: New understandings of grief. London, England: Taylor \& Francis.

Klass, D., \& Steffen, E. M. (Eds.). (2018). Continuing bonds in bereavement: New directions for research and practice. New York/London: Routledge.

Kübler-Ross, E. (1969). On Death and Dying. New York: Macmillan.

Lofland, L. (1978). The craft of dying: The modern face of death. Beverly Hills, CA: Sage. 
Steffen, E., \& Coyle, A. (2010). Can 'sense of presence' experiences in bereavement be conceptualised as spiritual phenomena? Mental Health, Religion \& Culture, 13, 273-291.

Steffen, E., \& Coyle, A. (2011). Sense of presence experiences and meaning-making in bereavement: A qualitative analysis. Death Studies, 35, 579-609.

Walter, T. (1996). A new model of grief: Bereavement and biography. Mortality, 1, 725.

\footnotetext{
${ }^{i} 1$. In the United States, due to the model of healthcare delivery that requires individuals to have private insurance, treatment including psychological therapy, is covered by insurance only if a health condition has received a diagnosis.
} 